Marquette University

e-Publications@Marquette

Theology Faculty Research and Publications

Theology, Department of

1-1-1999

\title{
Promise and Fulfillment in Hellenistic Jewish Narratives and in Luke and Acts
}

William Kurz

Marquette University, william.kurz@marquette.edu

Published Version. "Promise and Fulfillment in Hellenistic Jewish Narratives and in Luke and Acts," in Jesus and the Heritage of Israel. Eds. David P Moessner. Harrisburg, PA: Trinity Press International, 1999: 147-170. Permalink. (C) 1999 Trinity Press International (T\&T Clark). Used with permission. 


\title{
Promise and Fulfillment in Hellenistic Jewish Narratives and in Luke and Acts
}

\author{
William Kurz
}

\section{Introduction}

Within the overall series objective of studying the Acts of the Apostles in relation to the Gospel of Luke, and in comparison with other writings from the Lukan environment which had similar purposes and used similar procedures, I will investigate the motif of promise and fulfillment in Hellenistic Jewish narratives and the particular relationship between the Gospel of Luke and Acts. Some Hellenistic Jewish narratives, such as the Letter of Aristeas, did not seem to relate closely enough to promise-and-fulfillment motifs to include in this essay. Those narratives that are included - Luke, Acts, 1 and 2 Maccabees, the Jewish War and Antiquities of the Jews of Josephus, and the Septuagint versions of Tobit and Judith - differ significantly in genre, ranging from ancient historiography to fiction. They differ in taking a more obviously biblical approach (Luke and Acts, 1 Maccabees, Tobit) to having a more Hellenistic emphasis (2 Maccabees, Josephus, Jewish War and Antiquities of the Jews). From the start it must be specified " that the term "Hellenistic Jewish narratives" has been stretched to include original Semitic narratives current in Greek translation as part of the Greek Bible at the time of Luke and Acts, such as Judith, Tobit, and 1 Maccabees. The only extant complete narratives written originally in Greek, besides Luke and Acts, were 2 Maccabees and the published Greek works of Josephus. ${ }^{1}$

1. In response to a 1996 Catholic Biblical Association paper based on an earlier version of this essay, Anthony Saldarini recalled the fact of translation from Semitic originals to help explain the paucity of some Hellenistic elements. For a convenient edition of fragments, see Carl R. Holladay, Fragments from Hellenistic Jewish Authors, vol. 1: Historians, SBLTT 20 (Chico, Calif: Scholars Press, 1983).

Because of its well-known narrative of the Septuagint translation, the Letter of Aristeas was initially investigated as one of these Hellenistic Jewish narratives. That narrative, however, plays a minor role in what is usually and better categorized as an epistle with strong Hellenistic wisdom and symposium motifs. 
The motif of promises or prophecies and their fulfillment is a literary device for making sense of disparate episodes. It is not only a key intertextual motif within the Jewish scriptures, in both the Hebrew and more extensive Greek collections, but also between the scriptures and the two Lukan narratives, and between the Lukan Gospel and Acts. To varying degrees, this motif is also important in other Hellenistic Jewish narratives being considered.

\section{Promise-and-Fulfillment Themes in Luke and Acts}

Space permits only a brief recollection of the study of promise and fulfillment in Luke and Acts. The two most obvious levels are, first, the fulfillment of biblical promises and, second, the fulfillment of prophecies and promises made by characters, by Simeon, Jesus, the apostles, and so on. For example, the biblical promises to Abraham are a major theme in the Gospel infancy narratives. Prophecies by Jesus, such as passion predictions, are sometimes fulfilled later in the Gospel, in Acts, beyond Acts, or in the eschatological future. ${ }^{2}$ The Lukan version of the Last Supper (Luke 22:14-38) provides examples of fulfillment of both biblical prophecies and of Jesus' own prophecies.

\section{Promises Made in Jewish Scriptures, Fulfilled in Luke and Acts}

A consensus has emerged that Luke and Acts are thoroughly inspired by biblical motifs, vocabulary, writing styles, models, promises and prophecies, and other devices. ${ }^{3}$ The two volumes are grounded in God's saving history from the creation and Adam in Genesis (e.g., in Luke 1-3) to the eschatological parousia of the Son of Man (as in Luke 21). ${ }^{4}$ Already the preface to the Gospel makes a biblical allusion - granted, in nonbiblical Hellenistic idiom - to "events that

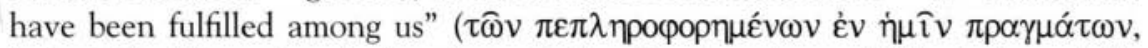
Luke 1:1). The style switches dramatically after the elegant Hellenistic periodic preface to a "barbaric" biblical style, from verse 5 through the rest of Luke 2, for the account of the announcements, births, and childhoods of John the Baptist

2. See William S. Kurz, S.J., Reading Luke-Acts: Dynamics of Biblical Narrative (Louisville: Westminster/John Knox, 1993), 57, 72, 142, 148; idem, "Acts 3:19-26 as a Test of the Role of Eschatology in Lukan Christology," SBLSP (1977): 309-23; John T. Carroll, Response to the End of History: Eschatology and Situation in Luke-Acts, SBLDS 92 (Atlanta: Scholars Press, 1988), 107-14.

3. For example, see Craig A. Evans and James A. Sanders, Luke and Scripture: The Function of Sacred Tradition in Luke-Acts (Minneapolis: Fortress, 1993); and Craig A. Evans and W. Richard Stegner, eds., The Gospels and the Scriptures of Israel, JSNTSup 104 (Sheffield: Sheffield Academic Press, 1994).

4. E.g., the Lukan genealogy grounds Jesus' human ancestry in "Adam [son] of God" (Luke 3:38); the eschatological sermon in Jerusalem culminates in the cosmic signs and glorious return of Jesus as eschatological judge (Luke 21:25-28). See William S. Kurz, "Luke 3:23-38 and GrecoRoman and Biblical Genealogies," in Luke-Acts: New Perspectives from the Society of Biblical Literature Seminar, ed. Charles H. Talbert (New York: Crossroad, 1984), 169-87; and idem, Reading Luke-Acts, $10-11,57,72,142,148$. 
and Jesus - an account full of allusions to biblical models and promises, as is the resurrection chapter (Luke 24). ${ }^{5}$

Regarding the Third Gospel's references to the fulfillment of scriptures and to God's saving plan, Fitzmyer points to the use of the terms $\pi \lambda \eta \rho \circ \hat{v} \nu$ and $\pi \dot{\mu} \mu \pi \lambda \alpha v \alpha$ from the infancy narrative onward. ${ }^{6}$ Especially noteworthy is the redactional use of fulfillment terms at turning points in both volumes: at Luke 9:51 ("And it happened in the fulfillment of the days of his being taken

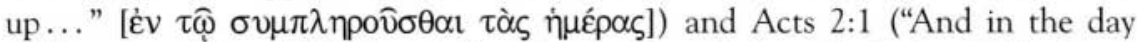

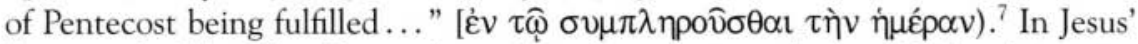
"inaugural address" at Nazareth, explicit mention is made that "Today this scrip-

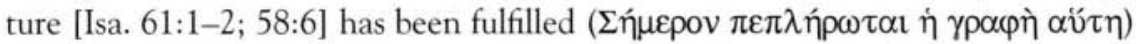
in your hearing" (Luke 4:21). Acts 2:16 explicitly claims that the Pentecost phenomena are the fulfillment of "what was said through the prophet Joel" (Joel 3:1-5 [LXX] in Acts 2:17-21). Overall, for example in Luke 4:21, 18:31, 21:22, $22: 37$, and 24:44, the notion of fulfillment in Luke shows the continuity of God's will as opposed to pagan notions of blind fate or chance. ${ }^{8}$

In the body of his Gospel (Luke 3-23), the author shares and sometimes augments the biblical allusions of both his main sources - the one responsible for readings common to all three Synoptic Gospels, and the one common only to Matthew and Luke ("Q") — as well as Luke's exclusive ("L") sources and materials. For example, as in Luke's other Gospel sources, John the Baptist fulfills the prophecy of "Isaiah the Prophet" (Luke 3:4-6). But Luke adds, in Luke 4:21, cited above, the mixed quotation of Isa. 61:1-2 (LXX) with 58:6.

Explicit mention of Old Testament predictions includes Luke 18:31, "Behold we are going up to Jerusalem, and all those things written through the prophets regarding the Son of Man will be fulfilled." In the Lukan Last Supper, after warning the disciples to be prepared, Jesus combines personal prophecy with reference

5. See William S. Kurz, "Narrative Approaches to Luke-Acts," Biblica 68 (1987): 195-220, esp. 206-8; idem, Reading Luke-Acts, 11-12, 19-23, 164-66; David E. Aune, The New Testament in Its Literary Environment, Library of Early Christianity (Philadelphia: Westminster, 1987), 66-67; cf. 82,128 .

6. Joseph A. Fitzmyer, The Gospel according to Luke (I-IX): Introduction, Translation, and Notes, AB 28 (Garden City, N.Y.: Doubleday, 1981), 1.292-93. Note also the recent argument (with references) explicitly linking the use of scriptures in Luke and Acts with the notion of God's plan, and with the related Hellenistic notion of providence: David P. Moessner, "The 'Script' of the Scriptures in Acts: Suffering as God's 'Plan' (Bovגń) for the World for the 'Release of Sins,' " in History, Literature, and Society in the Book of Acts, ed. Ben Witherington III (Cambridge: Cambridge University Press, 1996), 218-50. Cf. John T. Squires, The Plan of God in Luke-Acts (Cambridge: Cambridge University Press, 1993), comparing God's plan with the programmatic role of providence and the relationship to portents, epiphanies, prophecy, and fate in Hellenistic historiography.

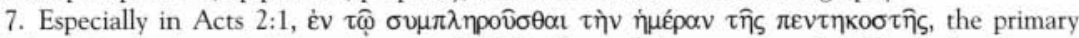
linguistic reference is probably to the arrival of the feast of Pentecost on the fiftieth day, but my translation suggests a double entendre: that the deeper meaning of the Jewish Pentecost is fulfilled in the events of Acts 2.

8. Gustav Stählin, "Das Schicksal im Neuen Testament und bei Josephus," in Josephus-Studien: Untersuchungen zu Josephus, dem antiken Judentum und dem Neuen Testament. Otto Michel zum 70. Geburtstag gewidmet, ed. Otto Betz, Klaus Haacker, and Martin Hengel (Göttingen: Vandenhoeck \&

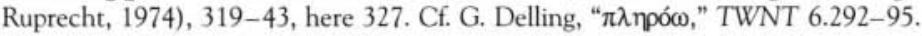


to scripture: "For I tell you that this which has been written ought to be fulfilled in me ( reckoned among the lawless,' for that [which is written] about me is nearing

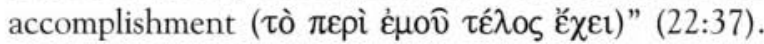

Predictions of sufferings in Luke 21 use explicit fulfillment language: “... because these are the days of punishment to fulfill all those things written

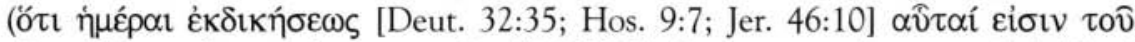

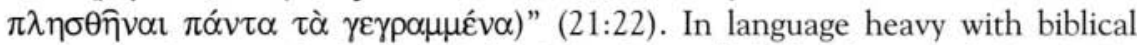
resonance, Jesus predicts in v. 24 that Jerusalem will fall by the sword (Jer. 21:7), be taken captive ( $\alpha i \chi \mu \alpha \lambda \omega \tau \imath \sigma \theta \eta \dot{\sigma} \sigma o v \tau \alpha$ ) by the nations (Ezra 9:7), and trampled by the Gentiles (Zech. 12:3 [LXX]; Ps. 79:1; Dan. 9:26; 1 Macc. 3:45, 51)

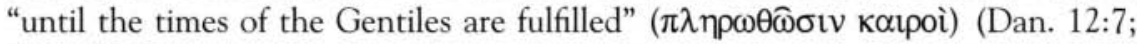
Tob. 14:5).

After Jesus' resurrection, angelic witnesses and the risen Jesus refer to previous predictions. All these references are distinctive to Luke. For example, the unrecognized Jesus calls the disciples on the way to Emmaus "slow of heart to

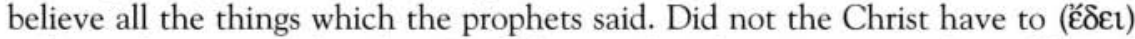
suffer and enter into his glory?" He then applies the scriptures to himself. "And beginning from Moses and from all the prophets, he interpreted for them in all the scriptures those things about himself" (24:25-27).

In a final appearance, the risen Jesus refers both to his own prophecies and prophecies of scripture. "'These are my words which I spoke to you while I was still with you, that all those things written in the Law of Moses and the prophets and the psalms about me must be fulfilled ( $\delta \varepsilon \hat{\imath} \pi \lambda \eta \rho \omega \theta \hat{\eta} \nu \alpha \mathrm{l})$.' Then he opened their minds to understand the scriptures. And he said to them, 'Thus it is written that the Messiah will suffer and rise from the dead on the third day, and there will be preached in his name repentance unto the forgiveness of sins to all the nations [or Gentiles], beginning from Jerusalem'” (24:44-47).

There is also consensus that Acts emphasizes fulfillment of biblical promises and prophecies, especially in the speeches. ${ }^{9}$ The speeches clearly proclaim that the age of fulfillment has dawned (see Acts 2:16 cited above). Acts 3:18, in a literal translation, reads: "What God has foretold through the mouth of all

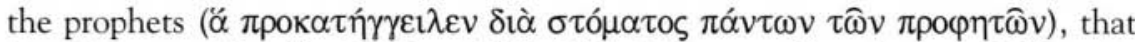
his Christ would suffer, he thus fulfilled" (غ่ $\pi \lambda \eta \dot{\rho} \omega \sigma \varepsilon v$ oú $\tau \omega \varsigma$ ). Acts 3:24 reads: "And all the prophets from Samuel and those following, as many as spoke, also

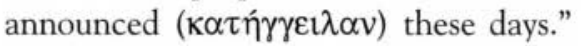

The Acts speeches also argue strongly that various events, such as the death of Jesus, were determined "by the set plan and foreknowledge of God" ( $\tau \hat{n}$

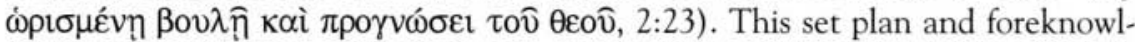
edge apply, for example, to the Davidic descent of the Messiah (2:30-31), to the Messiah's ministry $(2: 22)$, to his death $(2: 23$ and $3: 13-14)$, to his resurrection $(2: 24-31 ; 3: 15 ; 4: 10)$, to his exaltation at God's right hand $(2: 33-36 ; 3: 13$; 
$4: 11 ; 5: 30-31)$, to the Spirit as a sign of Christ's power and glory (2:33), and to the completion in Christ's return $(3: 21$; cf. 10:42, "the one appointed by God [o

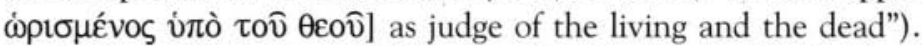

Further references to fulfillment of scriptural prophecies include Acts 13:29, "As they finished (Ė $\varepsilon \dot{\lambda} \lambda \varepsilon \sigma \alpha v)$ all those things written about him [Jesus], having taken him down from the tree they laid him in a tomb." The speech of Peter to Cornelius in Acts 10:43 concludes, "To this all the prophets witness

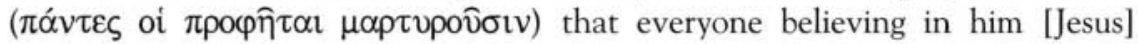
receives forgiveness of sins."

Another major motif in the Gospel and Acts that involves fulfillment of OT prophecy is the centrality of Jerusalem in God's plan, which was also pointed out by Fitzmyer. Thus, "events that have come to fulfillment among us" (Luke 1:1) include the stage-by-stage spread of God's word from Jerusalem to Judea and Samaria (Acts 8:1, 5, 26), to Caesarea Maritima (8:40), and Galilee (9:31), to Damascus (9:2), to Phoenicia, Cyprus, and Antioch in Syria (11:19), to the Roman provinces of Cilicia, Galatia, Asia, Macedonia, and Achaia, and finally to Rome (Acts $1: 8 ; 23: 11 \mathrm{c} ; 28: 14$ ). The fate of Jerusalem is also seen as a fulfillment of God's OT plan, for example, of Isa. 49:6 that "my salvation may reach to the end of the earth" (see Luke 2:32; Acts 13:47), or of Isa. 2:3 (=Mic. 4:2) that "out of Zion the Law shall go forth, and the word of the Lord from Jerusalem." And although the expression itself is not used, Jerusalem functions as the "navel of the earth" (Ezek. 38:12; cf. 5:5; Jub. 8:19). ${ }^{10}$

One of the most consequential themes for the plotting of Luke and Acts is that of fulfillment of God's biblical promises to Abraham, a fulfillment that takes place from the beginning in various characters and situations. Thus the introductory Lukan infancy account emphasizes the Abrahamic promises in the songs of Mary (Luke 1:55) and "prophecy" (1:67) of Zechariah (1:72-73). Whether people are children of Abraham is a major theme of the Baptist's preaching (Luke 3:8). The Lukan portrayal of Jesus' healings and conversions is the only one to emphasize the recipients as daughters or sons of Abraham (Luke $13: 16 ; 19: 9)$.

In Acts, the promise to Abraham is partially fulfilled in Moses, according to the speech of Stephen - "As the time of the promise which God swore to Abraham drew near..." (7:17). The speech depicts fulfillment of the promises according to a divinely planned periodization of Moses' life (Acts 7:20, 23, 30; compare the similar periodization which Luke 21 provides for the end times). The climax of this fulfillment of Abrahamic promises through Moses (and ultimately in Jesus) comes in Acts 7:37: "This is the Moses who said to the sons of Israel, 'God will raise up ( $\alpha \nu \alpha \sigma \tau \eta ́ \sigma \varepsilon \imath)$ a prophet like me from among your brothers.'”

Acts 7:37 reiterates the earlier statement in 3:22-23: "For Moses said that

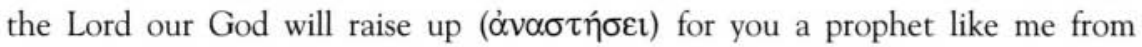

10. Fitzmyer, Luke I-IX, 168. 
among your brothers and sisters: listen to him according to whatever he says to you. For it shall be that every soul which does not heed that prophet will be cut off out of the people." This principle functions as a plotting strategy for the rest of Acts, demonstrating that Jews who refuse to accept the resurrected Jesus excommunicate themselves from God's people (cf. the climactic Acts 28:24-28, foreshadowed by Acts 17:4 and contrasted with 13:46 and 18:6). Jews who reject the Christian message are judged unworthy, and the message is taken to the Gentiles. This principle is a Lukan response to whether God kept the promises to the children of Abraham, given the large numbers from Israel that had not accepted the resurrected Messiah and therefore the fulfillment of biblical promises according to the Christian message.

\section{Prophecies Made and Fulfilled within the Gospel}

The predictions most central to the plotting of the Gospel are, as expected, Jesus' passion predictions, which foretell his death and resurrection. But the predictions also refer to aspects of plot development in Acts. Besides passion predictions which Luke shares with the "triple tradition" — Luke 9:22 parallels the first Markan passion prediction, Luke 9:44 the second, and Luke 18:31-33 the third - he includes several more: 9:31; 12:50; 13:33-35; 17:25; and the retrospective $24: 6-7,25-27$, and $44-47$, not to mention foreshadowings of the passion in the infancy narrative (such as Simeon's prophecy in 2:34-35).

Luke 9:22 is the first prophecy of Jesus' passion, and it is explicit: “...the Son of Man ought $(\delta \varepsilon \hat{\imath})$ to suffer many things and be rejected by the elders and chief priests and scribes and be killed and on the third day be raised." Luke 9:31 adds a peculiarly Lukan (and implicit) passion prediction, along with reference to scripture at the transfiguration, where Moses and Elijah are shown "speaking about [Jesus'] departure, which he was about to fulfill in Jerusalem ( $\tau \eta \grave{v}$ है

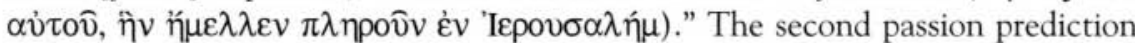
from the triple tradition is Luke 9:44: "The Son of Man is about to be delivered

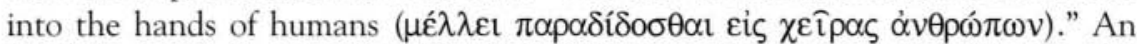
additional Lukan prediction comes within the eschatological comments in Luke 17:25: "But first he ought $(\delta \varepsilon \hat{\imath})$ to suffer many things and be rejected by this generation." The third prediction from the triple tradition in Luke 18:31-33 is quite detailed: "Behold we are going up to Jerusalem, and all the things written by the prophets about the Son of Man will be completed ( $\tau \varepsilon \lambda \varepsilon \sigma \theta \eta \dot{\sigma} \sigma \varepsilon \tau \alpha \mathrm{l} \pi \alpha \dot{v} \tau \alpha$

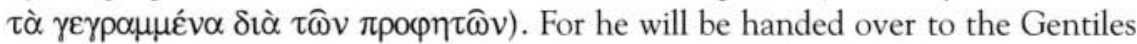
and ridiculed and insulted and spit upon, and after they scourge him they will kill him, and on the third day he shall arise." In Luke 24:6-7, the angel announces that Jesus has been raised: "Remember how he spoke to you while yet being in Galilee, saying that the Son of Man ought $(\delta \varepsilon \hat{\imath})$ to be handed over into the hands of sinful men and be crucified and on the third day arise."

An important concentrated source in the Lukan Gospel of the motif of prophecy, or promise and fulfillment, is its special redaction of the account of 
the Eucharist of the new covenant in 22:14-38. ${ }^{11}$ The opening of Jesus' farewell address clearly foreshadows his impending death: "With great longing I longed to eat this passover with you before I die" (22:15b). Then come two prophecies, "I will not eat it again until it is fulfilled $(\pi \lambda \eta \rho \omega \theta \hat{\eta})$ in the kingdom of God" (v. 16); and "from now on I will not drink from the fruit of the vine until the kingdom of God comes" (v. 18). The elements of the following institution of the Eucharist include promise, prophecy, and covenant, with the command to repeat the action liturgically (vv. 19b-20): "This is my body which is given for you [prophecy]. Do this in memory of me.... This is the cup of the new covenant in my blood which is poured out for you [prophecy]."12

Further intra-Gospel prophecies in this farewell are the prediction of Jesus' betrayal and the woe - a negative promise admittedly fulfilled after the Gospel - to his betrayer (22:21-22): "For the Son of Man goes as it is determined

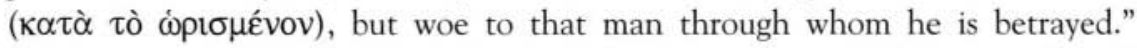
There is a special prophecy and promise for Peter: although Satan has desired to sift him like wheat, "I have prayed for you that your faith may not give out. And you, when you have repented, strengthen your brothers" (vv. 31-32, whose fulfillment begins in Luke 24 but is completed in Acts). A further prophecy, that Peter will deny knowing Jesus three times before the cock crows, follows Peter's protest (vv. 33-34).

\section{Promised Fulfilled in Acts, and after Acts}

A striking prophecy that receives its complete fulfillment only in Acts is the angel's annunciation to Mary, that her son "shall be called the Son of the Most High, and the Lord shall give him the throne of his father David, and of his kingdom there shall be no end" (Luke 1:32-33).

The main part of the Gospel contains other promises fulfilled in Acts. Luke 21:18's promise that "not a hair of your head" will suffer harm is echoed in Paul's reassurance to his shipmates in the storm (Acts 27:34). The prophecy of Jesus' return in the parousia (Luke 21:27) receives angels' reassurance of fulfillment after Jesus' ascension (Acts 1:9, 11). ${ }^{13}$ Jesus' promise to disciples in Luke 21:15 that he would give them wisdom persecutors could not withstand is fulfilled in Stephen (Acts 6:10). At the Last Supper in Luke 22:29-30, Jesus makes promises to the disciples in solemn covenant language, not to be fulfilled in their eschatological fullness until after the events of Acts: "And I appoint

11. William S. Kurz, "Luke 22:14-38 and Greco-Roman and Biblical Farewell Addresses," JBL 104 (1985): 251-68; idem Farewell Addresses in the New Testament (Collegeville, Minn.: Liturgical Press [Michael Glazier], 1990), 52-70.

12. With most scholars I accept the authenticity of the debated sections of vv. 19b-20; but even if they are not original most of my thesis holds, in any case for the canonical level of Luke. See esp. Bruce M. Metzger, A Textual Commentary on the Greek New Testament, 2d ed. (Stuttgart: German Bible Society, 1994), 148-50.

13. See Kurz, Reading Luke-Acts, 148. 
( $\delta \alpha \tau \tau i \theta \varepsilon \mu \alpha \mathrm{l})$ to you as my Father has appointed to me a kingdom... and you will sit on thrones judging the twelve tribes of Israel."

At the end of Luke, not only are Jesus' death and resurrection recounted, but the prophecy includes also Christian mission in his name, fulfillment of which does not occur until Acts. In addition, Jesus orders his disciples to wait in Jerusalem for their heavenly empowerment, for the promise (é $\pi \alpha \gamma \gamma \varepsilon \lambda i \alpha \nu)$ Jesus sends from the Father (Luke 24:49); this is also fulfilled in Acts. This remarkably detailed set of promises and prophecies summarizes much of the plot at the end of the Gospel and especially of the Acts of the Apostles.

A major Gospel theme not fulfilled until after Acts is the punishment of Jerusalem. In Luke 13:34-35 Jesus laments over Jerusalem, "who kills the prophets and stones those sent to you," and about his desire to gather her children - "but you [pl.] did not want [it]." Then he prophesies, "Behold your house shall be forsaken," and warns followers that they will not see him until they say, "Blessed is the one coming in the name of the Lord." In Luke 19:41-44, Jesus weeps over the lost chances and coming punishment of Jerusalem. "If you had only known in this day what was for peace; but now it is hidden from your eyes" (v. 42). Jesus makes explicit mention of the coming siege of Jerusalem (v. 43), and the dashing of her children to the ground (cf. Psalm 137:9). His explanation of the destruction is that hearers "did not know the time of your visitation" (v. 44), a thematic allusion to the failure to recognize when a promise or prophecy is being fulfilled (see esp. Acts 13:27).

On Jesus' way to The Skull, it is only in Luke where Jesus tells the women of Jerusalem to weep rather for themselves and their children. "For behold the days are coming," Jesus says, when the sterile will be blessed and people will call the mountains to "fall upon us" (Luke 23:28-30; Hos. 10:8). Finally, in Acts 6:14 Stephen is accused of claiming that Jesus would destroy Jerusalem. All these prophetic references by Jesus and his followers to the destruction of Jerusalem, which are also expressed in past biblical prophecy, clearly function as devices pointing beyond Acts to the destruction of the year 70, justifying the Christian response to this catastrophe and using it as evidence of fulfillment of God's wrath.

Another cluster important to Luke and Acts are references from Psalm 118 to Jesus as the stone rejected by the builders (Luke 20:17; Acts 4:11), which are closely related to the ending of Paul's Antioch of Pisidia speech (Acts 13:40-41). Paul claims that justification not possible through the law of Moses is available to everyone who believes in Jesus (vv. 38-39), and the speech ends with a warning: "Therefore see to it lest that said in the prophets comes

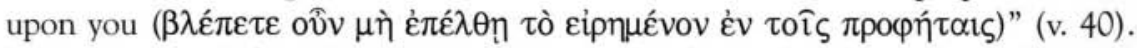
Verse 41 cites Hab. 1:5, warning despisers who do not heed or believe the work

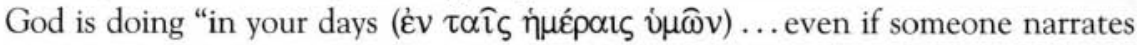

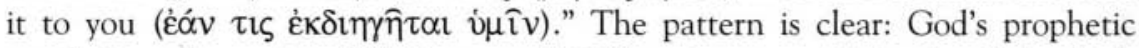
words from the past and their present fulfillments are not being heeded, which leads to judgment on the present "despisers." The rejection of Jesus recounted 
in Acts is presented as fulfillment of ancient biblical prophecies, and the punishment for this rejection, to take place after the ending of Acts, fulfills still other biblical warnings. ${ }^{14}$

Most scholars see Acts 1:8 as not only a prophecy by Jesus but also as a partial preview of the plot to come: You will receive power - the Holy Spirit comes in Acts 2 - and be my witnesses in Jerusalem (Acts 2-7), Judea and Samaria (Acts $8-9$ ), and to the end of the earth (Acts 10-28, esp. chaps. 26-28). ${ }^{15}$

\section{Promise-Fulfillment Themes in 1 Maccabees}

At first reading, 1 Maccabees, compared to Luke and Acts, seems to use little promise-and-fulfillment language. Closer analysis, however, reveals both the fulfillment of biblical prophecies and prophecies within the narrative. The text also implies fulfillment in indirect and allusive ways, clear enough for audiences steeped in scripture. The biblical style, narrative structure, and language of 1 Maccabees imply that the history of the Maccabees continues the biblical history.

An example of explicit fulfillment of biblical prophecies is 1 Macc. 7:16-17. After reporting that the priest Alcimus killed sixty Hasideans - who had trusted him because he was a "priest of the seed of Aaron" - the narrator quotes Ps.

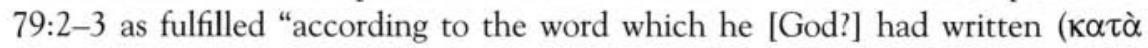

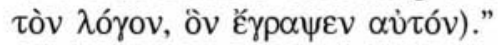

The use of biblical types for the heroes of 1 Maccabees shows that God guides events and that they fulfill a biblical plan of salvation. Thus Mattathias is modeled after the type of Phinehas, the zealous priest who defended the law from abuse, even to the point of killing the abuser (1 Macc. 2:23-26; Num. 25:6-15). The farewell speech of the patriarch Mattathias to his sons (1 Macc. 2:49-70), who would win battles and lead the people in the rest of the account, strongly implies that God's saving plan would be fulfilled in them.

A major structuring principle of this speech is the enumeration of biblical ancestors and forebears, listed as exempla of virtues for the sons to follow (2:5161). Even the narrative introduction, which Dimant argues is modeled on Jacob's testament in Genesis 49, sets the stage not only for the virtues exemplified in the list, but also for the overall plot. ${ }^{16}$ The list is introduced by an exhortation

14. See Jerome Neyrey, The Passion according to Luke: A Redaction Study of Luke's Soteriology, Theological Inquiries (New York: Paulist, 1985), 108-28.

15. E.g., compare Rudolf Pesch, Die Apostelgeschichte, vol. 1: Apg 1-12, EKKNT 5.1 (Neukirchen-Vluyn: Neukirchener, 1986), 65, 69-70, and the distinctions in Robert C. Tannehill, The Narrative Unity of Luke-Acts: A Literary Interpretation, vol. 2: The Acts of the Apostles, FFNT (Minneapolis: Fortress, 1990), 17-18.

16. See Devorah Dimant, "Use and Interpretation of Mikra in the Apocrypha and Pseudepigrapha," in Mikra: Text, Translation, Reading, and Interpretation of the Hebrew Bible in Ancient Judaism and Early Christianity, ed. Martin Jan Mulder (Philadelphia: Fortress; Assen, the Netherlands: Van Gorcum, 1988), 379-419, esp. 394-95. Mattathias emphasizes the difficulties his sons 
to "remember the deeds of your fathers" (cf. Sir. 44:1 [LXX], "Let us now praise

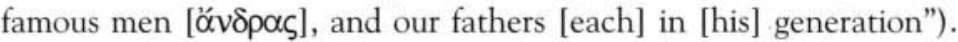

Especially important for 1 Maccabees' justification of the Hasmonean priesthood is the reference to "Phinehas our father," who because of his zeal "received a covenant of everlasting priesthood" (v. 54). ${ }^{17}$ Also of importance for what will happen in 1 Maccabees are Abraham's fidelity in testing (v. 52) $;^{18}$ Joseph's preservation of the commandment in distress (v. 53); Joshua's ascent to judgeship for keeping God's word (v. 55); Caleb's testimony in the assembly (v. 56); David's mercy and eternal kingdom (v. 57); Elijah's great zeal for the law (v. 58); the belief and salvation of Hananiah, Azariah, and Mishael (v. 59); and Daniel's innocence and consequent deliverance from lions (v. 60). ${ }^{19}$

A broader plotting convention implying fulfillment of promises is portrayal of the Maccabees in language reminiscent of earlier Israelite achievements (compare 1 Macc. 5:48 with Num. 20:17-20; 21:22), ${ }^{20}$ or in terms of Davidic messianic hopes coming to partial accomplishment in Maccabean deeds and successes. ${ }^{21}$ The book as a whole, beginning from the revolt of Mattathias and ending with the Hasmonean John Hyrcanus, justifies the Hasmonean dynasty by portraying its rise and solidification in terms reminiscent of biblical judges and kings. ${ }^{22}$ Thus God chose to free Judah from foreign oppression through Judas Maccabeus, often against overwhelming odds, as God had done through the judges (see esp. 1 Macc. 3:16-22). ${ }^{23}$ The final images of peace and prosperity in

face and their need to be zealous for the Torah and covenant, giving examples of zeal with corresponding outcomes. "Thus the list illustrates the principle, and serves as its model" (394). Listed good deeds are examples of zeal for Torah, though the term "zeal" is only used in 2:24, 26-27, 58 .

17. Ibid., 395. Phinehas's zeal comes from the Hebrew in Num. 25:13, with the phrase "covenant of everlasting priesthood" also from Numbers. (Compare the use of "zeal" for Elijah and Mattathias in 1 Macc. 2:26.) Zeal functions as the chief virtue at the beginning of this exhortation.

18. Ibid., 394. Compare Sir. 44:20 (LXX), "and in testing he was found faithful," an allusion to Gen. 22:1, "God tested Abraham," and Neh. 9:8, "you found his heart faithful."

19. Ibid., 395, summarizes the technique throughout this list: first, an explicit element (a name) is introduced and the most typical aspect about his life is summarized, using terms from the original source. Such lists actualize major biblical tenets.

20. Ibid., 407. Judas's request recalls the Israelites passing through the land of the Edomites and Amorites in Num. 20:17-20; 21:22: not only does it have the same motifs but some of the biblical text is interwoven. Deut. 2:26-29 is the basis, with details from other texts, and the refusal echoes that of the Amorites in Deut. 2:30. Thus 1 Maccabees implies that Judas enacts patterns of biblical history.

21. See the apparent allusions to David in the description of the rise of Maccabeus in 1 Macc. 3:1-4, cited below. See Jonathan A. Goldstein, 1 Maccabees: A New Translation with Introduction and Commentary, AB 41 (Garden City, N.Y.: Doubleday, 1976), 10-11, 244, 240-41, 248.

22. Compare the theme of the Maccabeans avenging their brother John in 1 Macc. 9:38 and 42 with the revenge of Levi and Simeon for the rape of their sister Dinah (Gen. 34:25-29), and the allusions to Amos 8:10 in "the wedding was turned into mourning..." (1 Macc. 9:41). Goldstein, 1 Maccabees, 526, also notes that 1 Maccabees ends (16:23-24) in the style of 2 Kings 20:20, by stating that the rest of the king's deeds are written in chronicles.

23. Note especially the principle: "There is no difference in the sight of heaven to save by many or by few: for not in multitude of the army is victory of battle, but the power is from heaven" (1 Macc. 3:18b-19). Note also the biblical pattern of dividing groups into companies (1 Macc. 3:55; cf. also the feeding of the five thousand), and having those with heavy obligations and the fearful leave the army before the battle (1 Macc. 3:56, following Deut. 20:5-8). 
1 Macc. 14:8-9, 12, 15 can be viewed as fulfilling Lev. 26:4; Zech. 8:12; Ezek. 34:27; Zech. 8:4; Isa. 52:1; and perhaps Isa. 60:10.24

For predictions within the narrative fulfilled later in the account, see especially the thematic clustering in Mattathias's farewell, which establishes the plot of events to come through prophecies, promises, and commands to his sons, the heroes of most of the remaining narrative. ${ }^{25}$ Thus Mattathias's exhortation to fight for the law is obeyed and accomplished throughout 1 Maccabees. The exhortation to give their lives for the covenant is fulfilled in the deaths of Judas and all his brothers, including lastly Simon, and also of some Hasmoneans from the next generation. The death of the sons receives special emphasis, as when Simon reminds the people, "You know how many things I and my brothers and the house of my father have done on behalf of the laws.... For this reason all my brothers have perished for the sake of Israel, and I alone am left" (13:3-4).

Mattathias's prediction that "Simon... will be to you as a father" $(2: 65)$ is realized in Simon's reign (chaps. 13-16). Mattathias's designation of Judas as commander (2:66) comes to pass immediately after Mattathias's death, and is first signaled by a poem to Maccabeus which seems to echo the David story: "And Judas called Maccabeus, his son, arose in his place, and all his brothers helped him .... and they waged the war of Israel with gladness, and he broadened the glory for his people and put on a breastplate like a giant and girded on his war armor .... and he was like a lion in his deeds" (3:1-4).

1 Maccabees also contends that events show that God gave both leadership and the high priesthood to the Hasmoneans, in whom Jewish hopes have been fulfilled. But the book cannot explicitly claim messianic fulfillment. Rather $1 \mathrm{Macc}$. 14:41 notes "that Simon should be their governor and high priest forever, until a

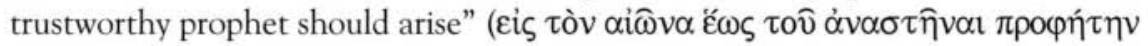
$\left.\pi ı \sigma \sigma^{v}\right)$. The term "forever," which justifies the dynasty stemming from Simon, is limited temporally (as were the dynasties in the Northern Kingdom) by the possibility that a true prophet might anoint another dynasty. ${ }^{26}$

\section{Promise-and-Fulfillment Themes in 2 Maccabees}

2 Maccabees has a different theology from 1 Maccabees, to the extent that some scholars see the two accounts as competing and as trying to supplant the

24. See Goldstein, 1 Maccabees, 491: "Simon's donations parallel both those of Solomon (1 Kings 6-7) and of Greek communal benefactors (e.g., Pseudo-Plutarch, Vitae decem oratorum 852b)."

25. Ibid., $8,12-13$, makes the distinction that since 1 Maccabees presumes at least a temporary cessation of prophecy after the last of the canonical prophets (cf. $4: 46 ; 9: 27 ; 14: 41$ ), it does not call these sayings prophecies but simply predictions.

26. Goldstein interprets "until a true prophet arise" as a compromise with other sects who may have expected a miraculous reappearance of the Davidic dynasty or coming of the Son of Man (see Ezra 2:63 and Neh. 7:65; Goldstein, 1 Maccabees, 507, esp. 508). 
other. ${ }^{27}$ It is also written in a different style from 1 Maccabees. Whereas 1 Maccabees is written in biblical style as a continuation of the biblical histories to the time of the Hasmoneans, 2 Maccabees is filled with Hellenistic language, style, concerns, and conventions - carried over in this epitomizer's condensation of the original five volumes of Jason of Cyrene. 2 Maccabees sounds less like biblical history, nor is it as explicitly dependent on such biblical motifs as promise and fulfillment. Promise-and-fulfillment themes, however, are not without importance.

One major aspect of promise and fulfillment centers around the martyrs, who died horrible but heroic deaths to be faithful to God's law in the face of human persecution. There are repeated promises that at the resurrection bodily members and limbs now being torn or cut off will be restored. Thus in 2 Macc. 7:9, the second brother prophesies that God "will resurrect us to an eternal revivification

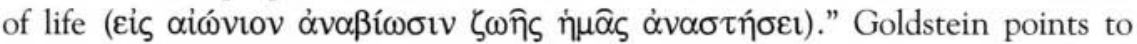
the redundancy and attributes it to an allusion to Dan. 12:2 (LXX; "will be resurrected to eternal life"). ${ }^{28}$

Neil McEleney points out that the mother's philosophical thoughts in 2 Macc. 7:22-23 are related to Ps. 139:13-16; Wis. 7:1-2; and Qoh. 11:5: ${ }^{29}$ "I do not know how you appeared in my womb, nor did I grant the spirit and life to you.... Therefore since it is the creator of the world who shapes the origin of

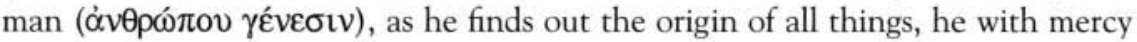
will give back to you the spirit and life...." Compare Qoh. 11:5 (LXX), "As there is none who knows what is the way of the spirit, how the bones grow in the womb, so you do not know the works of God...."

In 2 Macc. 7:14, the fourth brother contrasts the brothers' anticipated resurrection with the denial of resurrection for Antiochus. The brother dies in hopes "of being resurrected by him [God]; but for you [Antiochus] there will

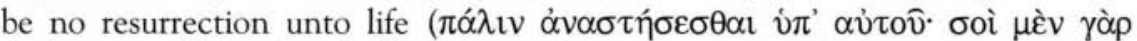

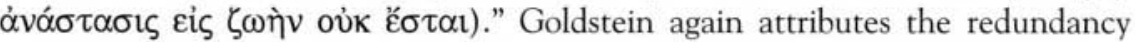
of "resurrection unto life" to an allusion to Dan. 12:2 (LXX), as well as to the Greek of Isa. 14:20-21, interpreted as meaning that Antiochus and his children will have no resurrection (esp. Isa. 14:21: "Prepare your children to be slain for the sins of your [their] father, in order that they may not rise and

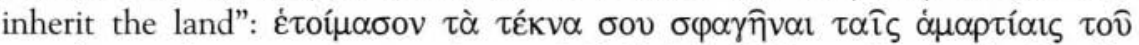

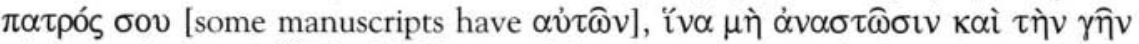
$\kappa \lambda \eta p \circ v 0 \mu \eta \tilde{\sigma} \omega \sigma \mathrm{v} v) .{ }^{30}$ The fulfillment of these promises, in which author and presumably the intended audience believe, remains, at the time of writing, in the

27. E.g., Goldstein, 1 Maccabees, 4, 33-34; idem, 2 Maccabees: A New Translation with Introduction and Commentary, AB 41A (Garden City, N.Y.: Doubleday, 1983), 82; George W. E. Nickelsburg, Jewish Literature between the Bible and the Mishnah: A Historical and Literary Introduction (Philadelphia: Fortress, 1981), 121.

28. Goldstein, 2 Maccabees, 305; cf. 64, 55 n. 2. See Goldstein, 1 Maccabees, 12, and 2 Macc. $7: 9,11,14,23,29,36 ; 12: 43-45 ; 14: 46$.

29. N. McEleney, "1-2 Maccabees," NJBC 444.

30. Goldstein, 2 Maccabees, 306. Greek from Rahlfs LXX text and apparatus. 
indefinite eschatological future. ${ }^{31}$ There is also expectation in 2 Macc. 2:4-8 as the prophet Jeremiah hides the ark of the covenant on the mountain of Moses, not to be found until a time of righteousness.

Some prophecies of characters within 2 Maccabees are fulfilled later in the narrative, as were the passion predictions of Jesus in Luke. An example early in the narrative are the pathetically described prayers of the pious for deliverance of the Temple, fulfilled when the Greek commander, Heliodorus, is diverted by a divine epiphany (2 Macc. 3:24-40).

The most emphatic examples in 2 Maccabees of fulfillment within the narrative are prophecies, promises, and warnings (i.e., negative promises) uttered by the seven sons martyred by the cruel tyrant Antiochus. ${ }^{32}$ Goldstein points out many allusions in the sons' statements (2 Macc. 7:16-19) to Dan. 8:24-25..$^{33}$ The author of 2 Maccabees has added biblical dimensions to the sons' prophecies through scriptural language and allusions. The sons' warning that Antiochus will be forced in death to confess that God alone is God (7:17, 19; esp. 7:31-37) is fulfilled. As Antiochus lies dying with excruciating bowel pain and swarming with worms, with rotting skin and a stench his army could not endure $(9: 4 b-10$; cf. v. 28), he confesses his sin and God's authority (9:11-18).

Other significant examples of fulfillment include purification of the Temple (10:1-8) and the foiling of Nicanor (chaps. 14-15), culminating in the sung praises to one "who has kept his place undefiled" (15:34).

\section{Promise and Fulfillment in Josephus's Jewish War and Antiquities of the Jews}

Like 2 Maccabees, the histories of Josephus comply explicitly with the standards and expectations of Greco-Roman historiography. The Jewish War (henceforth

31. Nickelsburg argues that the treatment of resurrection has roots in Second Isaiah Jewish Literature, 121). He refers specifically to suffering-vindication in Isaiah 52-53; to Antiochus's arrogance and punishment in 2 Maccabees 9 as related to Isaiah 14 (see pp. 86, 88, 178-79); to the Mother of Seven as equivalent to Second Isaiah's Mother Zion awaiting return of her dispersed sons ( 2 Macc. 7:17-29; cf. Isa. 49:14-23; 54:1ff.; 60:4-9). To the Mother of Seven's language Nickelsburg compares the interpretation of Second Isaiah in Baruch 4:17-29 (see pp. 112-13). To resurrection as new creation, he compares Second Isaiah's creation-redemption in 43:1-2, 6-7; 44:1-2; 46:3-4.

32. See Nickelsburg, Jewish Literature, 120, with special reference to 2 Macc. 7:17, 19, 31, 3537. Cf. McEleney, "1-2 Maccabees," 444, who writes that the vivid account in 2 Macc. 9:9-12 is heavily theological and echoes Isa. 66:24. See esp. Isa. 14:11, "Your glory has gone down to Hades, your great gladness; under you they shall spread rottenness, and your covering shall be a worm"

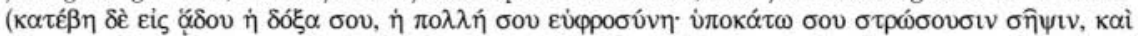

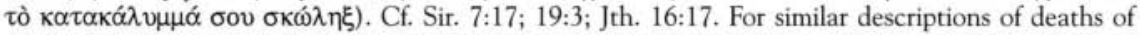
God's enemies, see Josephus, Ant. 17.6.5, 168-69, on Herod the Great, and Acts 12:23 on Herod Agrippa.

33. "You wield power" (2 Macc. 7:16) alludes to "his power shall be great" (Dan. 8:24); "work your will" (v. 17) to "he shall work his will"; "they [mutilations] pass belief" (v. 18) to "he shall cause destruction past belief" (Dan. 8:24; cf. Deut. 28:59, "The Lord will make your afflictions pass belief"); "having dared to contend with God" (v. 19) to "he shall rise against the Prince of princes" (Dan. 8:25) (Goldstein, 2 Maccabees, 306-7). 
War) conforms more to a "pragmatic" military and political history, as represented by Polybius, and the Antiquities of the Jews (henceforth Ant.) follows the rhetorical historiography of Josephus's model, Roman Antiquities of Dionysius of Halicarnassus. ${ }^{34}$ Nevertheless, the histories of Josephus also maintain the biblically prominent belief in promise and fulfillment, a belief which they sometimes recast in Hellenistic terminology.

Reasons for this become more evident when we consider Josephus and Luke-Acts from the perspective of "apologetic historiography.". ${ }^{35}$ Since these narratives, in telling the story of a subgroup within Roman culture, follow the group's traditions, but Hellenize them to describe the group's identity within the larger world, promise and fulfillment are important in relating the group's history to God's plan. ${ }^{36}$ Therefore it is necessary first to consider briefly how Josephus recasts biblical motifs in Hellenistic terms before investigating his two uses of promise and fulfillment - relating scripture to his narrative, and relating characters within his narrative to later fulfillment.

\section{Recasting Biblical Motifs in Hellenistic Terms}

The primary source of Josephus's belief in providence and the divine governance of history - the Bible - enunciates this belief primarily through covenantal motifs like promises, or prophecies, and fulfillment. To express this belief in his Greek writings, Josephus draws from Greek historiographical terminology for fate and providence, but also varies usage between War and Antiquities.

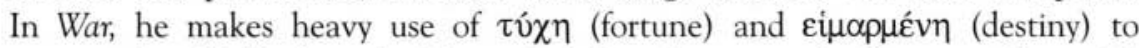
suggest that God's favor in history is being shown to the Romans. From this perspective he criticizes the revolutionary theologies that opposed Rome. In Antiquities, Josephus leans more on $\pi \rho o ́ v o r \alpha$ (providence) terminology as a substitute for the biblical theology of covenant and to express his belief in God's universal moral control. Josephus attributes God's favor to the Jews to their exemplary virtue, which was most like that of $\mathrm{God} .^{37}$ In the biblical section of Antiquities (Books 1-10), Josephus paraphrases the Bible with exegetical adjustments for his Greek audience. He combines the retributive theology of

34. Harold W. Attridge, "Jewish Historiography," in Early Judaism and Its Modern Interpreters, ed. Robert A. Kraft and George W. E. Nickelsburg (Philadelphia: Fortress; Atlanta: Scholars Press, 1986), 311-43, here 327.

35. Gregory E. Sterling, Historiography and Self-Definition: Josephos, Luke-Acts, and Apologetic Historiography, NovTSup 64 (Leiden and New York: Brill, 1992).

36. Ibid., 17. See pp. 308-10 on Josephus's definition of Judaism in historical terms. He defines the Jewish people through their own record rather than through Gentile misconceptions, but nevertheless in terms understandable to the Greek world.

37. Attridge, "Jewish Historiography," 326-27; cf. idem, The Interpretation of Biblical History in the "Antiquitates Judaicae" of Flavius Josephus, HDR 7 (Missoula, Mont.: Scholars Press, 1975), 71-144. 


\section{Deuteronomistic history with a $\pi \rho \operatorname{cov}_{\mathrm{v}} \alpha \mathbf{\alpha}$ concept of providence from Hellenistic historiography. ${ }^{38}$}

Gustav Stählin notes that when Josephus uses Hellenistic terms, such as

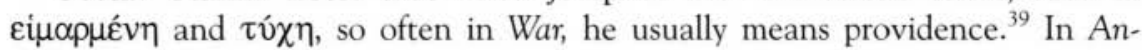
tiquities, the term "providence" refers primarily to God's retributive justice, intervening on behalf of the righteous or against the wicked. ${ }^{40} \mathrm{In}$ fact, this notion of retributive providence gives Josephus a theological framework for his biblical exegesis (Ant. 1.14). The main lesson is that those who follow God's will succeed and are rewarded, whereas those who depart from strict observance of God's laws find their efforts ending in disaster. ${ }^{41}$ The two major demonstrations of retributive providence are reversals ( $\pi \varepsilon p \iota \pi \varepsilon ́ \tau \varepsilon \imath \alpha$ ), especially miraculous rescues or horrific punishments, and prophecy ( $\pi \rho \circ \varphi \eta \tau \varepsilon i \alpha)$, which for this essay is the most important aspect. ${ }^{42}$

One important question relating to promise, or prophecy, and fulfillment is Josephus's treatment of prophecy and prophets after the close of the Hebrew Bible. It is true that Josephus mentions in Contra Apion 1.41, at the time of Artaxerxes, successor to Xerxes, an end to the succession of prophets. ${ }^{43}$ But whereas 1 Maccabees frequently refers to the (at least temporary) cessation of prophecy (e.g., 1 Macc. 4:46; 9:27; 14:41), Josephus's paraphrases of these passages in Antiquities routinely edit out such references. Thus, where 1 Macc. 4:44-47 referred to storing the profaned altar stones "until there should come a

38. Sterling, Historiography and Self-Definition, 297. On pp. 309-10, Sterling notes that in the more pro-Roman War, providence sustains Rome, whereas in the Antiquities, providence generally sustains Israel (but the examples are from Israel's ancient [biblical] past).

39. Stählin, "Schicksal," 336 (see n. 8 above for citation). But Stählin sharply distinguishes Josephus's use of such terms from the prophets' use, and accuses Josephus in some cases of going beyond Hellenistic language to borderline syncretism (334-38). He suggests that the turning point seems to be Josephus's $\mu \varepsilon \tau$ qóvor $\alpha$ to the Romans, with the corresponding claim that $\tau \hat{\chi} \chi \eta$ has gone to the Roman side (War 5.367, 2.360). Sometimes Josephus attributes this to God's will (War 3.354, 5.412; "Schicksal," 341). Josephus finds God closely bound to the $\tau$ x $\chi \eta$ of Rome and especially of Titus

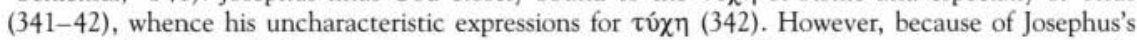
own situation and his link to the Romans, he seems to go beyond Pharisaism and comes precariously

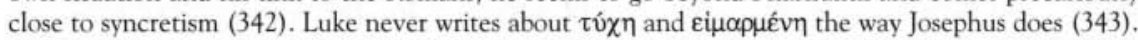

Attridge, however, disagrees with syncretistic interpretations of Josephus (Interpretation of Biblical History, 19-21, esp. 20-21 n. 3; and 154-55 n. 2). Attridge counters that Josephus does not just syncretistically import alien notions: he avoids fatalism and transforms Hellenistic antiquarian rhetorical

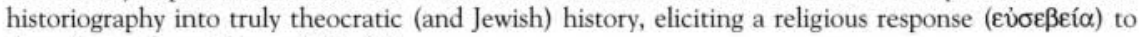
these facts of providence (182-84).

40. Attridge, Interpretation of Biblical History, 92 n. 1, argues that pronoia in the Antiquities refers not to God's plan for history, but to God's constant care that retributive justice be done among humans. He also believes that Josephus applies this concept of providence or forethought not only to God but to human leaders like Moses and others (71-72).

41. Cited by Maren R. Niehoff, “Two Examples of Josephus' Narrative Technique in His 'Rewritten Bible,'” JSJ 27/1 (February 1996): 31-45, here 33.

42. Attridge, Interpretation of Biblical History, discusses reversals (91-99) and prophecy (99-104; cf. 151).

43. Gerhard Delling, "Die biblische Prophetie bei Josephus," in Betz, Haacker, and Hengel, Josephus-Studien, 109 (see n. 8 above for full citation); cf. Rudolf Meyer, "Bemerkungen zum literargeschichtlichen Hintergrund der Kanontheorie des Josephus," in Betz, Haacker, and Hengel, Josephus-Studien, 319-43. 
prophet to tell what to do with them," Ant. 12.318 simplifies this to: "He [Judah] also pulled down the altar, and built a new one of various stones which had not been hewn with iron" (LCL). ${ }^{44} 1$ Macc. 9:27 mentions the cessation of prophets: "Thus there was great distress in Israel, such has had not been since the time that prophets ceased to appear among them." Ant. 13.5 ignores this prophetic reference: "After this calamity had fallen the Jews, which was greater than any they had experienced since their return from Babylon..." ${ }^{45}$ In fact, Josephus refers to postbiblical prophets, and refers to the high priest John Hyrcanus as a prophet (War 1.68-69). "He was the only man to unite in his person three of the highest privileges: the supreme command of the nation, the high priesthood, and the gift of prophecy ( $\pi \rho \circ \varphi \eta \tau \varepsilon i \alpha v) .{ }^{36}$ Sid Leiman argues that Josephus usually distinguishes these individuals from the succession of literary prophets which had ended, allowing for isolated instances of prophecy, but not literary prophecy. He also notes that Josephus usually uses different terminology. The term to refer to

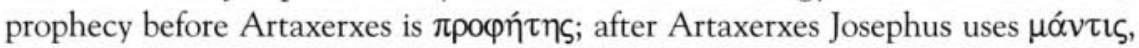
or a related Greek term. ${ }^{47}$

We have seen how in the biblical section of Antiquities Josephus tries to justify God's ways to Greeks, or to make theological corrections, or to find Hellenistic language to express the biblical account. ${ }^{48}$ Therefore much of the biblical dynamic of promise (or prophecy) and fulfillment does get translated into the Antiquities, although sometimes under Greco-Roman guise. What follows are a few examples, some well-known, illustrating Josephus's use of prophecy-and-fulfillment motifs in War and Antiquities.

\section{Promise-Fulfillment in Josephus, Jewish War}

\section{Scriptural Prophecies Fulfilled in or beyond the Narrative}

A well-known example, both in the ancient world, where it was referred to by other Roman historians, and among contemporary treatments of Josephus is the

44. Texts from 1 Maccabees (and also Antiquities) were cited in Isaiah M. Gafni, "Josephus and I Maccabees," in Josephus, the Bible, and History, ed. Louis H. Feldman and Gohei Hata (Detroit: Wayne State University Press, 1989), 116-31, here 118. Gafni also refers to passages from 1 Maccabees on p. 128 n. 21.

45. Cited in ibid., 119; Gafni's emphasis.

46. Josephus, The Jewish War, Books I-III, trans. H. St. J. Thackeray, LCL 2 (Cambridge: Harvard University Press, 1967), 34-35.

47. Sid Z. Leiman, "Josephus and the Canon of the Bible," in Feldman and Hata, Josephus, the Bible, and History, 50-58, here 56; cf. 58 n. 42 and its references. The word "usual". accounts for the exceptional applications of the term "prophet" to postbiblical figures listed by David E. Aune, "The

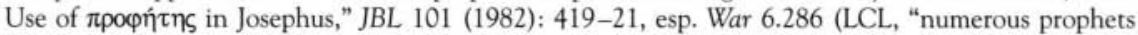

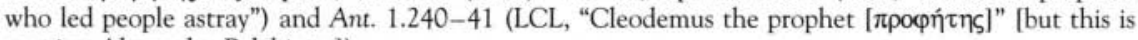
quoting Alexander Polyhistor]).

48. See Sterling, Historiography and Self-Definition, 222-24, on fragmentary Hellenistic Jewish predecessors to Josephus; see pp. 295-97 on theological control portrayed as providence, especially in rewarding virtue and punishing vice. 
"ambiguous oracle" prophecy. Apparently based on Num. 24:17, the prophecy stated that someone "from their [the Jews'] country" would become ruler of the world (War 6.313). Though the Jews interpreted this messianically, Josephus, who portrayed himself as a prophetic messenger (War 3.350-54, 400-401), applies the prophecy to Vespasian, who was named emperor while in Judea and who thus came "from their country" as a world ruler (War 6.312-13; cf. 3.352, $4.601-4) \cdot{ }^{49}$

Another significant example is Josephus's claim that the building of the Egyptian temple of Onias fulfilled Isaiah's prophecy: "There had, moreover, been an

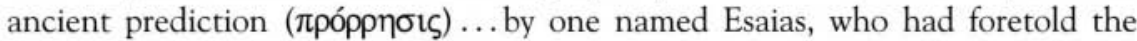
erection of this temple in Egypt by a man of Jewish birth" (War 7.432, LCL; cf. Isa. 19:18-19).

\section{Characters' Prophecies Fulfilled in or beyond the Narrative}

As treated above under Hellenistic recasting of biblical motifs, a significant element in the Jewish War are Josephus's references to postbiblical prophecies, even when not using biblical prophetic terminology. Notable is his well-known portrayal of himself as a prophet; more specifically, as a successor to prophets in distressing times. ${ }^{50}$ His self-portrait shows a strong predilection for the tradition of Jeremiah. Thus, Josephus provides an emphatic portrait of himself as a prophet of the destruction of Jerusalem, with significant allusions to the life and reception of Jeremiah in similar situations (War 3.400-402; 5.391-93). ${ }^{51}$

\section{Promise and Fulfillment in Josephus, Antiquities of the Jews}

\section{Scriptural Prophecies Fulfilled in or beyond the Narrative}

As one would expect, especially in the sections of the Antiquities that rewrite the biblical narratives, Josephus makes numerous references to fulfillment of biblical prophecies. Stählin points out one example, the claim of Ant. 8.418 that Ahab has fulfilled the prophecies of Elijah and Micaiah ben Jimla (1 Kings 21:19; 22:20)..$^{52}$ Delling refers to several instances. ${ }^{53}$ A good example is Josephus's statement in Ant. 7.214 that the prophecy of Nathan in 7.152 has been fulfilled: "And this [Absalom's publicly lying with David's concubines] came about in

49. See Paul W. Barnett, "The Jewish Sign Prophets, A.D. 40-70, Their Intentions and Origins," NTS 27 (1981): 679-97, esp. 686, and Stählin, "Schicksal," 332-33. Cf. Francesco Lucrezi, “Un' 'ambigua profezia' in Flavio Giuseppe," Atti della Accademia di Scienze morali e politiche della Società Nazionale 90 (1979): 589-631.

50. David Daube, "Typology in Josephus," JJS 31/1 (1980): 18-36, here 20.

51. Ibid., 20; cf. Stählin, "Schicksal," 333; Reinhold Mayer and Christa Möller, "Josephus Politiker und Prophet," in Betz, Haacker, and Hengel, Josephus-Studien, 284.

52. Stählin, "Schicksal," 332.

53. Delling, "Prophetie bei Josephus," esp. 111-13. 
accordance with the prophecy which Nathan had made when he revealed to David that his son would one day rise up against him" (LCL). Josephus's version of Nathan's prophecy went beyond the original in 1 Sam. 12:11 — "I will take your wives... and give them to your neighbor," fulfilled in 16:21-22 - to specify that "his wives would be violated by one of his sons" (emphasis mine). Josephus also mentions fulfillments of several of Elijah's prophecies, in Ant. 9.27 (the death of Ahab's son Ochozias [Ahaziah]); 9.119-20 (Jehoram's death in Naboth's field); 9.124 (the manner of Jezebel's death); and 9.129 (the perishing of Ahab's house).

\section{Characters' Prophecies Fulfilled in or beyond the Narrative}

Perhaps more significant for Josephus's purposes than showing fulfillment of biblical prophecies is relating prophecies within his account to their providential fulfillment. The relationship of providence to prophecy is stated clearly in Solomon's speech at the Temple dedication (Ant. 8.109-10), in which Solomon demonstrated God's providence by the fulfillment of prophecies of his father David. Soon after, the prophecy of Ahijah to Jeroboam is said to be fulfilled through the arrogance of Rehoboam (8.218). ${ }^{54}$ The theme is again developed at the end of Book 10, where the fulfillment of Daniel's prophecies foretelling destructions of Jerusalem by Antiochus Epiphanes and by the Romans is asserted to demonstrate God's providence. The assertion is made particularly against the Epicurean denial of providence (esp. Ant. 10.278-81). That God's retribution has been fulfilled as foretold proves that God exercises providential care. ${ }^{55}$

\section{Promise and Fulfillment in Tobit}

Tobit provides an example of how a different category of narrative - fiction uses the promise-and-fulfillment strategy. I will consider the same strategies in Tobit as I did for Luke and Acts: first, how prophecies from scripture are fulfilled either in or beyond the narrative; and second, how prophecies by characters within the narrative are fulfilled. Because Tobit has a fictional setting in the eighth century B.C.E., centuries earlier than its composition, probably in the second century в.C.E., it is not surprising to find ex eventu prophecies written in light of their "fulfillments," that is, in light of what is known to have happened.

\section{Scriptural Prophecies Fulfilled in or beyond the Narrative}

Of major influence on the Book of Tobit are the biblical prophets. Thus the descriptions of Israel's exile in Tob. 1:3-10, 3:1-5, 14:3-4, as well as of the return

54. Ibid, 100.

55. Ibid., 102-4. 
from exile in Tobit 13-14, are heavily influenced by the writings of the prophets Jeremiah, Ezekiel, and Deutero- and Trito-Isaiah. The plot exploits information and themes gleaned from these prophets, such as the abandonment of the Jerusalem Temple by the tribe of Naphtali (Tob. 1:4-5); Israel's exile as punishment $(3: 4-5)$; and the prophesied destruction of Nineveh and Jerusalem, Judah's exile and return, the destruction of the Temple and building of a replacement, and the final restoration of Jerusalem and the conversion of the Gentiles (14:4-7).

Other influences from the prophets include explicit references by the character Tobit. In 2:6, Tobit says: "I remembered the prophecy of Amos, how he said, 'Your feasts shall be turned into mourning...'" (Amos 8:10). This reference illustrates the sorrow at the murdered and unburied Jew that interrupted Tobit's Pentecost feast, increasing the pathos. But the change of perspective from Amos's judgment on Israel to Israel's suffering seems irenic, and leaves God more on Israel's side. In Tobit's farewell instructions to his son Tobiah in 14:4, he refers, depending on the manuscript, to the prophet Nahum or Jonah in warning Tobiah to move out of Nineveh. In the Sinaiticus manuscript, Tobit says, "I believe the word of God about Nineveh, as Nahum said" (Rahlfs). In the Vaticanus manuscript, Tobit says, "I am persuaded by as much as [ö $\alpha$ ] Jonah the prophet said about Nineveh" (Rahlfs). ${ }^{56}$

A different but also mostly ornamental reference to the prophets comes in Tobit's instructions to Tobiah in 4:12. Tobit tells Tobiah that he should wed within their tribe, "For we are sons of the prophets. Remember, my son, Noah, Abraham, Isaac, and Jacob, our fathers from of old, that they all took wives from among their brothers." Being a son of the prophets is mentioned as an incentive not to marry a foreign woman, and several ancestors are cited as examples.

\section{Characters' Prophecies Fulfilled in or beyond the Narrative}

In several instances Tobit refers to prophecies fulfilled later in the narrative or beyond. Some work strictly within the story as plot devices. Others are ex eventu references to events known to have occurred.

In 5:20-22, Tobit prophesies to his wife Anna that their son will return safely, and gives a reason which, in view of his ignorance of the angel Raphael's identity, is full of irony: "For a good angel will keep him company." This prophecy is fulfilled in Tobit 11. In 11:7-8, Raphael promises Tobiah that his father will regain his sight after Tobiah anoints him with fish gall. Raphael recounts details that the narrator will repeat when recounting the fulfillment: when Tobit's eyes smart "he shall rub them," which will scrape off the white film so that "he will see you." All is fulfilled almost immediately a few verses later in 11:11-13.

Tobit's farewell to Tobiah (chap. 14) is based on the motif of Deuteronomistic

56. The fact that, in Jonah, Nineveh is spared would presumably be viewed from this perspective as a temporary reprieve in light of the author's ex eventu awareness of its eventual destruction. 
retribution and makes significant use of ex eventu prophecies and fulfillments. ${ }^{57}$ In a prophetic warning, Tobit instructs Tobiah to move his family from Nineveh to Media after Tobit's and Anna's deaths. This is fulfilled at the end of the book (14:15), when Tobiah hears that Nineveh has been destroyed and rejoices over its fate. After Jonah (or Nahum) predicts the destruction of Nineveh in 14:4, $14: 4 b-5$ a prophesies that brethren in Jerusalem will be scattered (=Deut. 30:23 [LXX]; cf. Luke 21) "from the good land" (=Deut. 1:35; 3:25; 4:21, 22; and often). Jerusalem will become desolate. The house of God will be burned and remain desolate for a time, but the people will return and rebuild the Temple, "but not like the first." All the Jewish people will then return from their places of captivity, and Jerusalem and the house of God will again be glorious "as the prophets have spoken."

Tob. 14:6-7 makes the eschatological prediction that all nations shall convert, and that Israelites shall "dwell forever in the land of Abraham," referring to the promise to Abraham in Deut. 1:8 and elsewhere concerning "the land which the Lord your God swore to give to your fathers, Abraham, Isaac, and Jacob." For this wording compare the references in Deut. 12:10-11 (LXX) that they shall dwell in the land, receive their inheritance, find their promised rest,

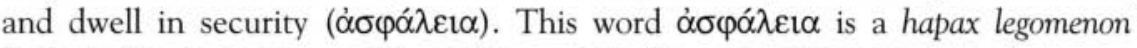
both in Deuteronomy and in Tobit, and in the rest of the Pentateuch occurs only in Lev. $26: 5 .^{58}$

\section{Promise and Fulfillment in Judith}

A second fictional narrative, Judith, can also be compared to Luke and Acts with respect to its use of promise and fulfillment. ${ }^{59}$

\section{Scriptural Prophecies Fulfilled in or beyond the Narrative}

As the farewell song by Tobit provided many key elements in that work, so does Judith's song of triumph, which is modeled on other songs by biblical heroines such as Miriam (Exodus 15) and Hannah (1 Samuel 2). Like these songs, Judith's song repeats the theme at the heart of much biblical narrative: that God's power,

57. See Alexander A. DiLella, "The Deuteronomic Background of the Farewell Discourse in Tob. 14:3-11," CBQ 41/3 (July 1979): 380-89.

58. Ibid., 383.

59. There is much scholarly indecision about the time and circumstances of the composition of the Book of Judith, though it was probably written originally in Hebrew and survives only in three slightly different Greek recensions, in one Syriac and in two Latin versions, and in some later Hebrew recensions. Because scholars find both Persian and Maccabean elements in the book, George Nickelsburg suggests that the story has two stages: that it originated in the Persian era and was rewritten in Hasmonean times ("Stories of Biblical and Early Post-biblical Times," in Jewish Writings of the Second Temple Period: Apocrypha, Pseudepigrapha, Qumran Sectarian Writings, Philo, Josephus, ed. Michael E. Stone, CRINT 2.2 [Philadelphia: Fortress; Assen: Van Gorcum, 1984], 46-52, esp. 51). 
as God of the lowly, depends not on numbers (Jth. 9:11). ${ }^{60}$ Though this theme does not usually occur in Judith as explicit biblical promise or prophecy, it relates to a similar idea of God's providence working through and for the chosen people.

The book's typology of the heroine Judith, as a weak human vessel - not a member of the warring class or army, but a woman - carrying God's power, relates to implied promises that God's power will work through human weakness. This typology is shared, for example, by Deborah and Jael (Judges 4-5) ${ }^{61}$ Jael's slaying of the oppressing general may well be a prototype for Judith's assassination of Holofernes. Such typology remains only implicitly promise and fulfillment.

Such themes and typology lend a paradigmatic quality to Judith in showing how God acts in history. Promise and fulfillment are only implicit in such a paradigm but the paradigm belongs to the biblical worldview that God acts providentially on people's behalf at crisis points in Jewish history. Especially striking are the paradigmatic uses of activism seen in both Judith and Mattathias (and in Phinehas, a prototype for them both). The treatment of Levi's slaughter at Shechem in Testament of Levi and Jubilees glorifies a somewhat similar activism. ${ }^{62}$

Nickelsburg suggests that Judith recalls several ancient heroes of Israel. If the book has a Hasmonean date, the name "Judith" seems an obvious allusion to Judas Maccabeus. ${ }^{63}$

\section{Characters' Prophecies Fulfilled in the Narrative}

A key statement in Judith is the mock prophecy of Holofernes: "Who is God except Nebuchadnezzar? He will send his power and will destroy them [Israelites] from the face of the earth, and their god shall not deliver them" (6:2-3) ${ }^{64}$ With this gauntlet cast between God and Nebuchadnezzar, the prophecy guides most of the events to follow.

Another key statement is Judith's prophetic critique that people cannot test or force God's hand with oaths or prayer (8:11-17). Instead, Judith recalls that the people once were exiled because they worshiped false gods. Since the present generation has remained faithful they can hope for God's deliverance, and can view the crisis as a test and pedagogical admonishment rather than as punishment and destruction $(8: 18-27)$. This prophetic critique and Judith's related

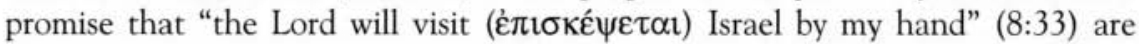

60. Ibid., 46.

61. Ibid., 48, suggests that Judith combines several heroines: Deborah and Jael; the woman of Thebez (Judg. 9:53-54); and the woman of Abel at Beth-maacah (2 Sam. 20:14-22).

62. Ibid., 48.

63. According to Nickelsburg, Jth. 13:7 recalls Samson in Judg. 16:28; Jth. 13:6-8 recalls 1 Sam. 17:51, in which David beheads Goliath with Goliath's sword; Jth. 9:2-3, 8-10; 13:6-8 recalls the patriarch Simeon (ibid., 49 n. 86).

64. See ibid., 46. 
fulfilled when the enemy general is overcome and the enemy routed (Judith $13-15)$.

\section{Conclusion}

The influence of fulfillment of promises or prophecies on the Lukan Gospel is clear. So is the influence of fulfillment motifs on the Acts of the Apostles. Both books make intensive reference to fulfillment of biblical prophecies. Both also contain frequent prophecies by characters like the prophet Simeon and Jesus in Luke, and like Jesus, Peter, and Paul in Acts. In addition, evidence seems to support the interrelationship of Luke and Acts through the influence of the promise-and-fulfillment motif on the transitions between the two books, and through frequent fulfillments in Acts of prophecies given in the Gospel. In many ways, the plot of the Lukan Gospel has not been completed at its end, but several strands require the continued narrative of Acts for their realization. One especially important strand is the place of Jerusalem in both Luke and Acts and its punishment, which was foretold by Jesus.

Even the initial promises of Simeon that Jesus will be both a "glory for his people Israel" and a "light for the nations" require the reports of Acts for their accomplishment. For despite Jesus' resurrection, by the end of the Gospel he can hardly be called the glory of the people Israel. Beyond Jesus' immediate disciples, significant numbers of people have not yet accepted Jesus. It takes large numbers of Jewish conversions in Acts - at Pentecost and after the healing of the lame man in Acts 2-3 - before Jesus can realistically be referred to as a glory for Israel. Accounts in the early chapters of Acts confirm the importance of Jerusalem that the Gospel had underlined, through such means as the inclusio of beginning and ending in the Temple. And only a few Gentiles in the Gospel are affected by Jesus; missionary outreach does not begin until Acts 8-13.

To name other key examples, the biblical promises relating to Abraham and the double Jewish rejection of the "prophet like Moses" - first in Jesus, then in the apostles - require Acts for their fulfillment. Many of the key sets of prophecies by Jesus, such as the eschatological scenarios in Luke 21 and the Last Supper predictions of Luke 22, look toward accounts of their fulfillment in Acts. Significant prophesied events like the destruction of Jerusalem and cosmic signs have to wait for their fulfillment even beyond Acts.

These patterns of prophecy and fulfillment from Hebrew scriptures to Luke to Acts and beyond, in the light of related patterns in other Hellenistic Jewish literature, also shed light on the meaning and significance of "Israel" at the end of Acts. ${ }^{65}$ Since Luke and Acts fairly consistently preserve Jewish connections for

65. See the annotated bibliography in Joel B. Green and Michael C. McKeever, Luke-Acts and New Testament Historiography, IBR Bibliographies 8 (Grand Rapids, Mich.: Baker Books, 1994), sec. 5.5, "Judaism, the Jewish People, and the Gentiles," 61-71. 
the phrase "the people," and since they consistently place prophecies concerning the people Israel on a continuum from Hebrew scripture to the Gospel to Acts, it seems clear that Christians in Acts are considered to have inherited the biblical name and promises concerning "the people" and, hence, "Israel." A similar sense of continuity with the biblical people Israel runs through 1 and 2 Maccabees, Josephus's Jewish War and Antiquities of the Jews, and Septuagint versions of Tobit and Judith.

But unlike authors of those Hellenistic Jewish narratives, the author of Luke and Acts has a further pressing problem - competing claims to the heritage of Israel between Jews who have accepted Jesus as their Messiah, and the apparently much greater numbers in both Jerusalem and the Diaspora who have not. This issue is further complicated with the incorporation of uncircumcised Gentiles into this people after Acts 10-11.

We have seen how the quotation from Deut. 18:19 and Lev. 23:29 in Acts $3: 23$ is meant to explain some Jews' refusal to listen to Jesus as their selfexcommunication from the people of God, from Israel. It is also well-known how Acts 10-11 and Acts 15 tried to provide biblical warrant to scriptural and contemporary visions (as to Peter and Cornelius) for including uncircumcised Gentiles into "the people," in effect, into Israel.

Thus at the end of Acts, when Paul quotes Isa. 6:9-10 as the Holy Spirit's words "to your ancestors" (Acts 28:25-27), preceding promises give this Isaiah passage the sense of Paul's final drastic warning to the Jews of Rome - who still remain members of God's people - not to resist the message and excommunicate themselves from "the people" (Acts 3:23). In this sense, it seems that the question of Israel remains "open." 66

The survey of other Hellenistic Jewish narratives confirms the likelihood that it is not eisegesis to find promise-and-fulfillment plotting in the two Lukan volumes, and from the first narrative to the second. Though the forms and frequency of such plot devices varied greatly among these various historical and fictional narratives, most exhibit some dependence on plotting in light of biblical promises and God's plan for Israel. 1 Maccabees portrays much of the history of the Maccabees in terms reminiscent of biblical judges and David. The martyr theology and expectations of resurrection in 2 Maccabees probably draw on Daniel 12. Josephus recasts many biblical motifs, including promise and fulfillment, in Hellenistic terms, especially by subsuming promise and fulfillment under the broader notion of God's retributive providence. In his rewriting of the Bible in Antiquities, Josephus frequently underlines how later events fulfill earlier prophecies. Much of the fictional plot of Tobit is structured and enhanced with the help of ex eventu scriptural prophecies. Judith is portrayed in light of biblical heroines Deborah and Jael, and her song echoes those of Miriam and Hannah.

66. See esp. Vittorio Fusco, "Luke-Acts and the Future of Israel," NovT 38 (1996): 1-17; cf. Darryl W. Palmer, "Mission to Jews and Gentiles in the Last Episode of Acts," RTR 53 (1993): $62-73$. 
To a lesser but still meaningful extent, the significance of fulfillment of characters' predictions within the narratives can also be found. 1 Maccabees clusters predictions in Mattathias's farewell that structure much of the ensuing narrative about his sons. Predictions in 2 Maccabees of punishment for Antiochus are fulfilled later. Josephus portrays himself as a prophet like Jeremiah whose predictions (especially concerning Vespasian) are later fulfilled. Prophecies by characters in Tobit motivate their fulfillment shortly thereafter. Judith's prophetic critique of the people and her prophecy that the Lord will visit Israel by her hand are plot devices fulfilled in her overcoming of the enemy Holofernes.

Luke and Acts shared with most of these works from Hellenistic Judaism an immersion in the biblical sense of God's providence and plan as demonstrated in promises and prophecies and their fulfillment. Such a widespread and deepseated biblical worldview provides confirming evidence for the narrative linkage between the Lukan Gospel and Acts. Not only do the events in Acts fulfill the prophecies made by characters in the Lukan Gospel, but Luke and Acts together continue the biblical history of the fulfillment of God's promises. 